\title{
LINGUISTIC TYPOLOGY AND THE RECONSTRUCTION OF THE INDO-EUROPEAN ACCUSATIVE PLURAL
}

\author{
KenNeth ShieldS, JR. \\ Millersville University \\ kenneth.shields@millersville.edu

\section{TIPOLOGÍA LINGÜÍSTICA Y LA RECONSTRUCCIÓN DEL ACUSATIVO PLURAL INDOEUROPEO}

\begin{abstract}
In light of the fact that the traditional reconstruction of the Indo-European non-thematic accusative plural suffix *-ns, as the combination of the accusative desinence $*_{-} m$ and the plural ending $*_{-s}$, violates a linguistic universal which stipulates: «If morphemes of both number and case are present and both follow or both precede the noun base, then the exponent of number almost always comes between the noun base and the exponent of case» (The Universals Archive of the Association for Linguistic Typology), this article explores a possible etymology of the suffix which is consonant with that universal. Specifically, a proposal based on what Adrados 1992 calls «the new image of Indo-European» is developed in which both elements of the suffix are construed as original deictic particles.
\end{abstract}

Keywords: Indoeuropean; accusative; plural number; linguistic typology.
Teniendo en cuenta que la reconstrucción tradicional del sufijo *-ns del acusativo plural no temático del indoeuropeo, en tanto que combinación de la desinencia de acusativo *- $m$ y la terminación de plural $*_{-s}$, viola un universal lingüístico que estipula que «si están presentes morfemas tanto de número como de caso $\mathrm{y}$ ambos siguen o preceden al nombre base, el morfema que expresa el número casi siempre aparece entre el nombre base y el morfema que expresa el caso» (The Universals Archive de la Association for Linguistic Typology), este artículo indaga una posible etimología del sufijo acorde con ese universal. Específicamente, se plantea una propuesta, basada en lo que Adrados (1992) llama «la nueva imagen del indoeuropeo», en la que ambos elementos sufijales se reconstruyen como partículas deícticas originales.

Palabras clave: indoeuropeo; acusativo; número plural; tipología lingüística.

It is widely recognized today that «linguistic typology can profitably be utilized in order to determine the possibility or probability of reconstructions» (Song 2001, p. 305). That is, reconstructions which are compatible with general principles of language structure and change are to be preferred to those which are not. Of course, as Hock 1991, p. 626, points out, «even the best typologies cannot possibly cover the evidence of all attested languages, 
not to mention their earlier historical stages or the many languages which have died out unrecorded. Under these circumstances it is premature to reject palpable comparative evidence simply because it does not agree with current typological findings». However, when two equally reasonable comparative reconstructions are proposed and one is typologically-motivated and the other lacks such typological justification, the former should logically be chosen as the better hypothesis regarding historical developments. It is in the context of this simple argument that I wish to consider two proposals about the reconstruction of the Proto-Indo-European accusative plural desinence - the first of which is traditional but lacking typological motivation, and the second of which is, in my view, equally defensible from the historical data but fully compatible with an important typological generalization.

The Indo-European accusative plural suffix of non-thematic stems is traditionally reconstructed as $*_{-n} n-s$ (cf. Szemerényi 1996, p. 160), based on such correspondences as Skt. -as, Gk. -as $<*-n-s$. According to the traditional view, «the acc. s., as indicated by the correspondence [Skt.] -am : [Gk] $-a \ldots$, had the ending $-m$, i.e., the ending $-m$ which in final position after a consonant had to become syllabic» (Szemerényi 1996, p. 165). This same accusative marker is found in the plural ending *-n-s, but with assimilation «from $-m s$, i.e. $-m$ of the singular + pluralizing -s» (Szemerényi 1996, p. 160; cf., e. g., nom. pl. Skt. -as, Gk. -es). However, this reconstruction of the accusative plural suffix is in violation of a typological universal identified in The Universals Archive of the Association for Linguistic Typology: «If morphemes of both number and case are present and both follow or both precede the noun base, then the exponent of number almost always comes between the noun base and the exponent of case». This universal is characterized there as «almost absolute», with the reconstructed Proto-Indo-European accusative plural desinence listed as the sole counterexample. In what follows I wish to develop an alternative, typologically-consistent argument for the etymon of the $s$-element of this reconstructed suffix - an argument based on research within the «new image» view of the evolution of Indo-European morpho-syntax.

The term «new image of Indo-European» was coined by Adrados 1992 to describe the growing theoretical viewpoint that reconstructions of IndoEuropean morpho-syntax must take into account evolution within the protolanguage itself from an early uninflected stage to «the most recent phase ... which is practically that of traditional [Brugmannian] reconstruction: in this type, stems were opposed to mark tenses and moods in the verb, the masc. 
and fem. genders, and degrees of comparison in the adjective» (Adrados 1992 , p. 1). This «successive strata» approach to Indo-European morphosyntax «is opposed to the traditional one which merely sets out to reconstruct one type of IE, a type that is of course polythematic and from which the different Indoeuropean dialectal groups and languages would have sprung» (Adrados 1992, pp. 1-2). In regard to nominal inflection, I have argued for many years (cf., e. g., Shields 1982) that at an early stage of development «Indo-European ... possessed only two cases - a nominative and an objective - and that the latter later bifurcated into an accusative and an oblique», which underlay the so-called adverbial cases (dative, instrumental, locative, ablative, and genitive) attested in the historical dialects (Shields 1987, p. 343). At this early stage, number was not yet a viable inflectional category (cf. Shields 1991-1992) ${ }^{1}$. The original exponent of the nominative case was *- $\varnothing$ (cf. Kuryłowicz 1964, pp. 197-198), while the inflectional marker of the objective was $*-N(=m$ or $n)$. The original objective value of the latter is suggested by the fact that it is historically attested in a wide range of case functions. In addition to its common accusative role, it can be seen residually as a marker of oblique cases like the genitive (pl. Gk. -ōn, Skt. - $\bar{a} m$, Lat. -um), dative (Go. Dam-ma, Lith. tam-ui, OCS tom-u 'that,' cf. Schmalstieg 2004, p. 5), and instrumental (OCS sg. - $m$ b). Such an interpretation of these data is

${ }^{1}$ Such a view is also supported, for example, by Lehmann 1974, pp. 201-202, who maintains: «The system of verb endings clearly points to an earlier period in which there was no verbal inflection for number .... For the dual and plural endings are obviously defective. We cannot reconstruct endings in these two numbers which are as well supported as are those of the singular, except for the third plural .... The number system is defective in substantival as well as in verbal inflection. The personal pronouns never did introduce expressions for plurality, as suppletive paradigms indicate, e.g., Hitt. $u k$ 'I,' $u \overline{e s s ~ ' w e, ' ~ e t c ., ~ i n ~ c o n t r a s t ~ w i t h ~ d e m o n-~}$ stratives, e.g., kāas, $k \bar{e}$ 'this, these,' and nouns, e.g., antuhšaš, antuhšeš 'man, men' .... Number accordingly was not consistently applied in late PIE and the early dialects in accordance with natural reference. Subsequently application became more regular, and number congruence was carried out for both substantives and verbs». The variability in number specification into the dialectal period of suffixes like Gk. - phi and Hittite genitive -an and -aš especially indicates the original lack of formal inflectional number categories in Indo-European. I have also long adopted the position that the attested plural and dual numbers of the historical dialects derive from an original non-singular inflectional category, which subsequently bifurcated into these two grammatical numbers (cf. Shields 1982, pp. 63-72, 1991-1992, 2004). The late emergence of the dual is suggested, for example, by the fact that Hittite - an archaic dialect - never did develop productive inflectional dual affixes (cf. Ivanov 1958). 
also implied by the fact that «the original meaning of the accusative case was extremely broad. Krys'ko 1997, p. 252, wrote that A. V. Popov 1881 showed with many examples that the accusative in the Indo-European languages can perform all the functions which other cases perform and showed that the object function of the accusative is the result of the refinement and differentiation of the primary 'independent' (circumstantial-defining) meaning of the accusative, the case of the object in the broad sense, indeed, not an object, but a disseminator of the action» (Schmalstieg 2004, p. 7). Kuryłowicz 1964, pp. 181-183, similarly notes such «secondary» functions of the IndoEuropean accusative case as «acc. of direction», «acc. of 'contents'», «acc. of temporal extension», «acc. of spatial extension», and «acc. of relation» - all of which reveal that the case category originally had a far more general grammatical function embracing the expression of «locational» relationships.

During the course of the emergence of specific adverbial cases from the objective, inflectional polymorphy (cf. Wandruska 1969, p. 218) -the expression of the same category through a variety of different morphological markers - became normative. Different dialect groups subsequently chose different morphological elements as the exponents of inherited categories. This development explains why, for example, «the instrumental singular shows no united formation in Indo-European. Forms corresponding to the $-\bar{a}$ which is the regular ending in Indo-Iranian, appear only in certain languages, and there only in certain classes of stem. In addition there appear the endings -bhi (Gk. theóphi, Arm. mardov) and -mi (OCS vlıkomb, Lith. sūnumi). The former element is that which appears in the inst. pl. in Sanskrit (-bhi-s). In Greek it is used indifferently either as singular or plural, and further in a wide sense, covering instr., loc., and abl. Hittite has a different form of its own $(-\bar{e} t) \gg$ (Burrow 1973, p. 232). I have argued extensively elsewhere (cf., e. g., Shields 1987, 1993, 1994, 2000, 2003, 2005a, 2005b) that the source of this polymorphy was «the slow process of assigning specific grammatical functions to various enclitic deictic particles (... [e. g.,] *-(e/o)s, *-i, *-t, *-bh, $*_{-} e / o, *_{-} u$ and their contaminations [cf. Cohen 1984] ${ }^{2}$ ) which came to serve as exponents of the oblique case (cf. Markey 1979, p. 65). It is because this process of grammaticalization and functional specialization allowed for multiple analyses and because it extended into the period of dialectal develop-

\footnotetext{
${ }^{2}$ All of these Indo-European deictics have been independently reconstructed for many years. In this regard, see Hirt 1927, pp. 10-13.
} 
ment that there is such a great variety of attested formations» (Shields 1987, p. 343). Adrados 2007, p. 8, likewise attributes the lack of uniformity in the final evolutionary stage of Indo-European to the fact that the proto-language «was constantly developing, advancing, diversifying, its branches influencing each other. What a terrible, ingenuous, childish error to consider it as a single language, created in all its details once and forever!».

Of course, at the core of this process involving the grammaticalization of deictic particles (or adpreps) as case markers - a process which has been widely recognized both as a universal evolutionary tendency (cf. Heine, Claudi \& Hünnemeyer 1991, p. 167) and as a development within IndoEuropean (cf. Lehmann 1993, p. 154) - is simple reanalysis, which «changes the underlying structure of a syntactic construction, but does not modify surface manifestation» (Campbell 1999, p. 227). Since «at an early stage of Indo-European», deictics «constituted the formal indication of ... time, place and person» (Markey 1979, p. 65), these elements subsequently underwent fission with noun stems (cf. Fairbanks 1977, pp. 116-120). It was this development which led to the possibility of their being reanalyzed as genuine inflectional case markers, i. e., their «receiv[ing] regularized paradigmatic assignment» (Markey 1979, p. 66). However, in some dialects the older nonparadigmatic use of such deictics in fusion with nouns is preserved. Thus, «in Gothic alone of the Germanic dialects, $-b h$ - forms adverbs of manner» rather than indicating a true adverbial case function (Markey 1979, p. 65) 3 $^{3}$.

Within the context of this «new image» approach to Indo-European morpho-syntax, it is a simple matter to develop an etymology of the accusative plural suffix *-ns which is both consistent with the data and typologically motivated. The inflectional element $*_{-n}(<*-m)$ is indeed simply the reflex of the old objective marker $*_{-} N$, which is also directly attested in the accusative singular. It should be noted that although $*_{-} N$ was retained as the most frequent exponent of the accusative function in Indo-European, this function was not solely manifested by this element, for as deictic particles came to be used to express a variety of grammatical relationships originally embraced by the old objective case, these particles at times came to mark the classic accusative as well. For example, Schmalstieg (1980, p. 70) points out the

\footnotetext{
${ }^{3}$ Although Adrados 1989 also maintains that reanalysis underlies the appearance of case markers in Indo-European, he proposes that it manifests itself primarily in the reinterpretation of root enlargements and in «false cuts» of lexical forms.
} 
existence of «a few examples where the etymological $*_{-} i$ has been retained in some forms which we term accusative»; for example, «in Old Irish the accusative singular of ben 'woman' in the oldest texts is bein, but according to Thurneysen 1946, p. 184, from the time of the Würzburg glosses on the dative form mnai is used for the accusative. It is usually stated that the accusative singular form mnai is formed by analogy with the dative singular ..., but this does not seem to be a necessary assumption». Likewise, in Shields 1994, I maintain that the element $-u$ - of the Hittite accusative plural suffix $-u \check{s}$ is a retention of the deictic particle ${ }^{*} u$ as an accusative desinence.

As far as the inflectional element $*_{-s}$ of the suffix $*_{-n s}$ is concerned, I would like to propose that it represents a reflex of the deictic particle *(e/o)s, which had become blended with the old objective affix in *-m. Blendings of deictic particles with other deictics as they evolved into case inflections and with extant inflections was very common in Indo-European. Thus, the traditionally reconstructed dative singular desinence *-ei (cf., e. g., Skt. - $\bar{e}$, Lat. $-\bar{l})$ constitutes a blending of the particles $*_{e}$ and $*_{i}$ (Shields $2005 \mathrm{~b}$ ), while the locative plural affix in $*_{-s i}(\mathrm{Gk} .-s i)$ and $*_{-s u}$ (Skt. $-s u$ ) derives from the blending of $*(e / o)_{s}$ and $*_{i}$ and $* u$ (Shields 2007, p. 134). Similarly, the instrumental ending *-bhi (Gk. sg./pl. - phi) reflects a blending of the deictics *bh(e/o) and $*_{i}$. On the other hand, the instrumental suffix *-mi (OCS sg. -mb) is a blending of the old objective desinence $*_{-} N$ and the deictic $*_{i}$ - a direct parallel to the blending of objective $*-N$ and deictic $*(e / o)_{s}$ in the accusative.

In Shields 1992, p. 29, I provide extensive support for the reconstruction of a deictic in $*(e / o) s$, especially in light of the existence of a demonstrative stem in $*_{s o}$ (cf. Skt. sá[s], Gk. hó, Go. sa) since deictic particles typically serve as the etymological source of demonstratives (cf. Brugmann 1911, p. 312$)^{4}$. More recently, I point out that the third person demonstrative $a s ̌ i$ 'yon' of Hittite (cf. Goedegeburre 2002-2003, p. 1) in all likelihood derives from a blending of the deictics $*(e / o)_{s}$ and $* i$ and that the etymologically related Hittite distal adverbial form āšma (cf. Hoffner 2002-2003, p. 81) also contains a reflex of $*(e / o) s$ (Shields 2007, pp. 134-136). In addition to its grammaticalization in the locative and accusative cases, *(e/o)s appears also, for example, in the instrumental (cf., e. g., Skt. $-b h-i-s)$, the genitive (cf., e. g., *-(e/o)s: Skt. -as, Gk. -os, Lat. -is), and even the dative of personal

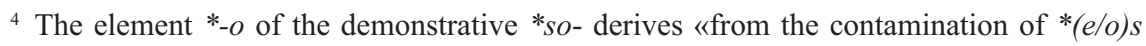
and the deictic $* o$ or from the thematization of $*(e / o) s »$ (Shields 1992, p. 29). 
pronouns in Germanic ( $1^{\text {st }}$ pers. sg. Go. mi-s, ON mé-r; see Shields 2000 for details).

Now as inflectional number categories began to emerge in late IndoEuropean and the early dialects (cf. Shields 1991-1992, 2004), certain of the extant accusative suffixes, i. e., *-ns, which served as polymorphic exponents of that category came to be specialized as indicators of the plural (nonsingular) number. In short, such suffixes came to constitute true portmanteau morphemes expressing case and number (and gender) as single morphological entities. In regard to *-ns (and suffixes like the instrumental in *-bhis), the association with plurality may have been encouraged by the fact that a plural suffix in *-(e/o)s (cf. nom. pl. *-elos: Skt. -as, Gk. -es) eventually appeared ${ }^{5}$. This is not to say that the $*_{-s}$ of $*_{-} n s$ was formally reanalyzed as a plural suffix since such a reanalysis would be a violation of the universal prompting a reconsideration of the etymology of $*_{-} n s$. Rather, the formal similarity of the morphologically internally-unanalyzable accusative suffix $*_{-n s}$ and the morphologically internally-unanalyzable (nominative) non-singular suffix *-(e/o)s prompted greater affinity in their functional roles as a result of the iconic tendency to align form and meaning (cf. Anttila 1989, p. 107)

Thus, in the context of the "new image» view of Indo-European, the origin of the traditionally reconstructed accusative plural suffix $*_{-} n s$ can be naturally explained without positing an exception to the linguistic universal involving the relative ordering of the exponents of case and number.

${ }^{5}$ On the basis of typological considerations (cf. Markey 1987), I have argued that *-(e/o)s and other Indo-European non-singular endings may have their origin in deictic particles (see Shields 1991/92 and 2004 for details). It is quite common for the same deictic particles to serve as the etymological basis for a variety of inflectional forms as a language evolves (cf. Hopper \& Traugott 1993, pp. 116-117, Shields 1997). Hopper \& Traugott 1993, pp. 116-117, calls this phenomenon «the characteristic of 'divergence'», whereby «the original lexical form may remain as an autonomous element», subject to further linguistic change. Thus, Hazelkorn 1983, p. 10, observes that, in Finno-Ugric languages, «deictic particles, which originally referred to the participants in the communication act and to their location, came to be used as definiteness markers [i. e., demonstratives, personal pronouns, possessive suffixes, and subject agreement markers in verbs], in order to indicate the focus of an utterance. In subsequent developments, these same elements came to be interpreted as on the one hand, person markers and, on the other hand, accusative markers, plural markers, etc.».

${ }^{6}$ Of course, once certain suffixes in final $*_{-s}$ had become associated with the non-singular, this formal component of these suffixes may have been extended analogically to other inflectional forms which came to assume non-singular value. 


\section{REFERENCES}

Adrados, F. R. 1989: «Agglutination, Suffixation or Adaptation? For the History of Indoeuropean Nominal Inflexion», IF 94, pp. 21-44.

- 1992: «The New Image of Indoeuropean: The History of a Revolution», IF 97, pp. 1-28.

— 2007: «Must We Again Postulate a Unitary and Uniform Indo-European?», IF 112 , pp. 1-25.

Anttila, R. 1989: Historical and Comparative Linguistics, $2^{\text {nd }}$ ed., Amsterdam, Benjamins.

Association for Linguistic Typology, «Universal Number 7», The Universals Archive, 17 December 2008 〈http://typo.uni-konstanz.de/archive/nav/search.php?».

Brugmann, K. 1911: Grundriss der vergleichenden Grammatik der indogermanischen Sprachen, vol. 2.2, Strassburg, Trübner.

Burrow, T. 1973: The Sanskrit Language, rev. ed., London, Faber \& Faber.

Campbell, L. 1999: Historical Linguistics: An Introduction, Cambridge, MA, The MIT Press.

Cohen, G. 1984: «Reflections on the Primitive Indo-European Locative Particles», KZ 97, pp. 13-21.

Fairbanks, G. 1977: «Case Inflections in Indo-European», JIES 5, pp. 101-131.

Goedegeburre, P. 2002-2003: «Hittite $3^{\text {rd }}$ Person/Distal Demonstrative aši (uni, eni, etc.)», Die Sprache 43, pp. 1-32.

Hazelkorn, L. T. 1983: «The Role of Deixis in the Development of Finno-Ugric Grammatical Morphemes», Ohio State University Working Papers in Linguistics 27, pp. 89-139.

Heine, B., Claudi, U. \& Hünnemeyer, F. 1991: Grammaticalization: A Conceptual Framework, Chicago, University of Chicago Press.

Hirt, H. 1927: Indogermanische Grammatik, vol. 3, Heidelberg, Winter.

Hock, H. H. 1991: Principles of Historical Linguistics, $2^{\text {nd }}$ ed., Berlin, Mouton de Gruyter.

Hoffner, H. 2002-2003: «Hittite $a$-aš-ma», Die Sprache 43, pp. 80-87.

Hopper, P. \& Traugott, E. C. 1993: Grammaticalization, Cambridge, Cambridge University Press.

Ivanov, V. V. 1958: «The Importance of New Data Concerning Hittite and Tocharian Languages for the Comparative Historical Grammar of Indo-European Languages», in Sivertsen, E. (ed.), Proceedings of the Eighth International Congress of Linguists, Oslo, Oslo University Press, pp. 611-614.

Krys'ko, V. B. 1997: Istoričeskij sintaksis russkogo jazyka, Moscow, «Indrik».

Kuryłowicz, J. 1964: The Inflectional Categories of Indo-European, Heidelberg, Winter. 
Lehmann, W. P. 1974: Proto-Indo-European Syntax, Austin, The University of Texas Press.

- 1993: Theoretical Bases of Indo-European Linguistics, London, Routledge.

Markey, T. L. 1979: «Deixis and the $u$-Perfect», JIES 7, pp. 65-75.

- 1987: «The Semiotics of Enumeration: The Case for Indo-European», JIES 15, pp. 93-96.

Schmalstieg, W. 1980: Indo-European Linguistics: A New Synthesis, University Park, Pennsylvania State University Press.

- 2004: «The Common Origin of the *-O Stem Dative, Accusative and Instrumental Cases», Baltistica 34, 1, pp. 5-11.

Shields, K. 1982: Indo-European Noun Inflection: A Developmental History, University Park, Pennsylvania State University Press.

- 1987: «Some Remarks about the Dual of Indo-European o-Stems», JIES 15, pp. 341-352.

- 1991-1992: «The Emergence of the Non-Singular Category in Indo-European», Lingua Posnaniensis 34, pp. 75-82.

- 1992: A History of Indo-European Verb Morphology, Amsterdam, Benjamins.

- 1993: «The Origin of the Armenian Locative Plural», JIES 21, pp. 55-62.

- 1994: «On the Origin of the Hittite Accusative Plural Suffix -UŠ», Hethitica 12, pp. 79-85.

- 1997: «On the Pronominal Origin of the Indo-European Athematic Verbal Suffixes», JIES 25, pp. 105-117.

- 2000: «Germanic Dative Personal Pronouns in *-S», Folia Linguistica Historica 20, pp. 25-35.

- 2003: «On Tocharian Genitives in A - (y)äp, B -epi», Tocharian and Indo-European Studies 10, pp. 97-103.

— 2004: "The Emergence of the Dual Category in Indo-European: A "New Image" and Typological Perspective», IF 109, pp. 21-30.

- 2005a: «On the Indo-European Genitive Suffix in *-E/O», Emerita 73, pp. 233-239.

- 2005b: «Some Comments about the Indo-European Dative Singular», Studia Etymologica Cracoviensia 10, pp. 157-163.

- 2007: «Hittite aši, āšma and the Deictic Origin of Indo-European Sigmatic Verbal Formations», Studia Etymologica Cracoviensia 12, pp. 133-138.

Song, J. 2001: Linguistic Typology: Morphology and Syntax, Harlow, Pearson Education.

Szemerényi, O. 1996: Introduction to Indo-European Linguistics, $4^{\text {th }}$ ed., Oxford, Clarendon.

Thurneysen, R. 1946: A Grammar of Old Irish. Trans. D. Binchy \& O. Bergin, Dublin, Institute of Advanced Studies. 
Wandruszka, M. 1969: «Polymorphie und Polysemie», in Engel, U., Grebe, P. and Rupp, H. (eds.), Festschrift für Hugo Moser, Düsseldorf, Pädagogischer Verlag Schwann, pp. 218-232.

Fecha de recepción de la primera versión del artículo: 23/05/2009 Fecha de recepción de la versión definitiva del artículo: 09/01/2010 Fecha de aceptación del artículo: 08/01/2010 